University at Buffalo School of Law

Digital Commons @ University at Buffalo School of Law

Winter 1-1-1974

\title{
Some Determinants of the Method of Case Disposition: Decision- Making by Public Defenders in Los Angeles
}

Lynn M. Mather

University at Buffalo School of Law

Follow this and additional works at: https://digitalcommons.law.buffalo.edu/journal_articles

Part of the Criminal Law Commons, Law and Politics Commons, and the Law and Society Commons

\section{Recommended Citation}

Lynn M. Mather, Some Determinants of the Method of Case Disposition: Decision-Making by Public Defenders in Los Angeles, 8 Law \& Soc'y Rev. 187 (1974).

Available at: https://digitalcommons.law.buffalo.edu/journal_articles/861

(C) 1974 Law and Society Association. Reproduced with permission.

\section{IN COPYRIGHT}

This Article is brought to you for free and open access by the Faculty Scholarship at Digital Commons @ University at Buffalo School of Law. It has been accepted for inclusion in Journal Articles by an authorized administrator of Digital Commons @ University at Buffalo School of Law. For more information, please contact lawscholar@buffalo.edu. 


\title{
SOME DETERMINANTS OF THE METHOD OF CASE DISPOSITION: DECISION-MAKING BY PUBLIC DEFENDERS IN LOS ANGELES
}

\author{
LYNN M. MATHER Dartmouth College
}

AUTHOR'S NOTE: This article is a revised version of a paper, "To Plead Guilty or Go To Trial?" presented at the 1972 annual meeting of the American Political Science Association. I wish to thank Martin Shapiro, Laura Nader and Nelson Kasfir for their helpful comments, and the attorneys, judges and court staff in Los Angeles for their cooperation and assistance.

\section{INTRODUCTION}

Only a small fraction of the criminal cases in the United States are decided by adversary trial processes. The vast majority are settled by guilty pleas; many of these pleas occur after some form of plea bargaining - either explicit negotiations over the entry of a guilty plea in exchange for a reduced charge or a lenient sentence, or tacit bargaining, as when the defendant pleads guilty in anticipation of lenient sentencing. The most frequently cited reason for plea bargaining is administrative expediency or "its utility in disposing of large numbers of cases in a quick and simple way" (Enker, 1967: 112). While caseload pressures are doubtlessly important, they may be overemphasized in the current literature. ${ }^{1}$ Frequently both the prosecutor and the defendant want to avoid a full jury trial because of the risk and uncertainty involved. The prosecutor is under administrative and/or political pressure not to lose his case; a negotiated plea of guilty, even if on a reduced charge, is a sure conviction, while conviction by trial is never certain. The defendant's risk at trial is that his sentence on conviction may be much stiffer than if he had pleaded guilty.

That defendants are concerned with minimizing their possible punishment points to a crucial aspect of the disposition process: the importance of sentencing. The adversary trial proceeding is designed to resolve the conflict over guilt or innocence. In practice, however, it is not the issue of guilt which is disputed in most criminal cases, but it is the issue of sentencing (Barrett, 1967; Mileski, 1971). Barrett (1967: 29) notes that police and prosecutors screen out a large proportion of doubtful cases at early stages, so that:

Most of the cases left to be dealt with by the system then are those in which there is no serious dispute over the guilt or in- 
nocence of the defendant. This fact sets the tone for the process. . . . Everyone concerned-the defense lawyer, the prosecutor, the judge, the probation officer-becomes aware of the fact that he is involved in a process where the primary focus is on deciding what to do with people who are in fact guilty. In that context one cannot expect the system to conform to the conventional adversary model.

Plea bargaining, unlike trial, does focus on the issue of what to do with an offender - particularly in deciding how much leniency will be given in return for a plea of guilty. Decisions on disposition "do not call for the yes-or-no answers of guilt or innocence. They seek to predict the offender's future behavior and the impact on the community of what is done to him" (Rosett, 1967: 76). Plea bargaining facilitates compromise decisions by allowing the use of mitigating information on the nature of the crime and the defendant. This information, which may be relevant to sentencing, is difficult to introduce at trial because of standards of "relevance" of evidence.

The relationship between sentencing and plea bargaining was suggested over 40 years ago by writers concerned with the compromise of criminal cases. Moley (1929: 187-88) wrote:

The whole tendency [to ccmpromise cases] represents a drift in the direction of individualizing the treatment of offenders. What actually should happen in all criminal cases is an attempt to adjust treatment to the needs of the individual case though statutory penalties make this difficult. Yet such individualization is at the heart of most forward-looking reforms of recent times, particularly probation. ${ }^{2}$

While the majority of cases are settled by a plea bargaining process, some criminal cases are still decided by adversary trial. This paper addresses itself to the question: what determines whether a case will be settled by plea bargaining or trial? In some ways, this study is following a recommendation made in 1927 to study "the types of cases in which compromises are most frequent and the reasons for such compromises" (Miller, 1927: 29). It has been suggested that the trial proceeding represents the failure of attempts to settle the case by bargaining (Jacob, 1965; Skolnick, 1967). This paper also asks: To what extent is this true? What determines the success or failure of plea bargaining. Focusing on the relationship between plea bargaining and trial may lead to a better understanding of the use and functions of each.

The defense attorney plays a key role in the defendant's decision to plead guilty or not guilty, and different considerations - may be involved for private attorneys and Public Defenders (Sudnow, 1965; but see Skolnick, 1967, for a contrary view). This 
paper will be limited to the decision-making of Public Defenders in their handling of cases for plea or trial resolution. The research reported here is from a study of felony disposition processes in the Superior Court of Los Angeles County (Central District).

The methodological approach of this study comes from ethnography. Ethnography "seeks to account for the behavior of a people by describing the socially acquired and shared knowledge, or culture, that enables members of the society to behave in ways deemed appropriate by their fellows" (Frake, 1969: 123). This study, then, attempts to describe the behavior involved in settling criminal cases and to account for this behavior by describing aspects of the court culture. Field work conducted in 1970-71 included interviews with attorneys, judges and court staff, analysis of case files, some statistical analysis, and five months of observation in court. Contrary to my original research plans, I had virtually no contact with defendants. Although defendants provide the reason for the court's existence, they do not share directly in the culture of the court. ${ }^{3}$

The Los Angeles Superior Court is the largest single trial court in the nation, serving a population of over 7 million in the County of Los Angeles; the court handles over one-half of the felony cases in California. Processes of case disposition vary considerably from one criminal court to another, so before presenting my data on Los Angeles, I will briefly discuss recent descriptive studies of urban courts. Three patterns of felony case disposition can be distinguished: guilty plea with prosecutor dominant; guilty plea with judge dominant; and not guilty plea with shortened trial.4

The first pattern is the conventional image of criminal courts where a very high proportion of cases are disposed of by pleas of guilty-perhaps $80-95 \%$ of the convictions are by pleas. And, further, the prosecutor's office dominates the proceedings by its initial screening and its explicit negotiations with defendants and their attorneys. The negotiations may concern the charge or the sentence; in either case, the court tends to approve routinely the bargains agreed to by the prosecutor. This pattern Characterizes plea bargaining in Detroit (President's Commission, 1967: Appendix B; McIntyre and Lippman, 1970), Houston (Fertitta, 1969; Busch, 1969; McIntyre and Lippman, 1970), Washington, D.C. (Subin, 1966), much of Michigan and Kansas (Newman, 1966), and "Metropolitan Court"s (Blumberg, 1967): lasud

The second pattern shows an equally high proportion of guilty plea convictions but here judges rather than prosecutors tend to 
control the dispositional process. For instance, in Brooklyn (Trammell, 1969; Meglio, 1969; McIntyre and Lippman, 1970) and Chicago (Oaks and Lehman, 1968; McIntyre, 1968; McIntyre and Lippman, 1970) police file felony complaints directly into the lower court system without prosecutorial screening. Lower court judges then dispose of the majority of complaints either by dismissal or reduction to a misdemeanor charge. At the trial court level in Brooklyn, judges participate in the plea negotiations at a mandatory pretrial conference in open court. In Chicago's trial court, there is some explicit negotiation between prosecutor and defense counsel, but there are also informal discussions with the judge over the likely sentence if the defendant were to plead guilty. Data for Minneapolis (Levin, 1970; 1971) and for many areas of Wisconsin (Newman, 1966) show a variation on this pattern; although these courts also have a high percentage of convictions by guilty plea, explicit plea bargaining is infrequent. Instead, tacit bargaining occurs, whereby defendants are encouraged to plead guilty by the known tendency of judges to penalize with more severe sentences defendants who plead not guilty.

Finally, some courts do not fit either of the above patterns because the majority of defendants plead not guilty. Most are then convicted by an abbreviated form of trial before a judge, without jury. This third pattern of case disposition characterizes Pittsburgh (Alschuler, 1968; Levin, 1970; 1971), Philadelphia (Alschuler, 1968; White, 1971), Baltimore (President's Commission, 1967: Appendix B; Fertitta, 1969; Busch, 1969; McIntyre and Lippman, 1970) and Los Angeles (UCLA Law Review, 1968; Meglio, 1969; Trammell, 1969; McIntyre and Lippman, 1970; Greenwood, et al., ${ }^{6} 1973$ ). Because of the frequency of trials, the judge's role is quite important, but the prosecutor's office may still exercise significant influence. In Pittsburgh and Philadelphia, many of the not guilty pleas are "slow pleas"7 (of guilty) with a brief informal trial where the defense presents material to influence the judge for leniency in sentencing. In Baltimore there are a massive number of court trials- about $80 \%$ of the felony defendants plead not guilty! Just over one-half of the defendants in Los Angeles plead not guilty; many then submit their cases to the court (without jury) on the basis of the transcript of the preliminary hearing-a procedure which often operates as a. "slow/ plea" of guilty.

The next section of this paper presents an overview of felony dispositions in Los Angeles. This includes a general description of the court, the pre-trial screening process, the sentencing patterns, 
and the methods of disposition. The two sections following present the ethnographic data on case disposition. The final section pulls together factors determining the method of case disposition and offers some corroborating statistical data.

\section{OVERVIEW OF FELONY DISPOSITIONS IN LOS ANGELES}

\section{Description of the Court}

In 1970 there were 31,571 felony defendants ${ }^{8}$ disposed of in Los Angeles Superior Court (Bureau of Criminal Statistics-hereafter B.C.S., 1970: 12). A large staff of attorneys was employed to handle this enormous caseload. The District Attorney's office had approximately 430 lawyers; there were about 350 lawyers in the Public Defender's office. In both offices appointments and promotions were made on the basis of a civil service merit system. The majority of defendants in Superior Court - an estimated $60 \%$ in 1970 - were represented by attorneys in the Public Defender's office."

The most common offense charged was a violation of the drug laws, for which $44 \%$ of the defendants were prosecuted; $90 \%$ of those cases involved marijuana or dangerous drugs ("pill cases"). The second most common offense was burglary, which was charged against $15 \%$ of the defendants. (See Table II in the Appendix for further data on offenses.) One-half of the defendants were under 25 years of age. Although Mexican-Americans and blacks comprised about $25 \%$ of the population of the county, they appeared as almost one-half of the defendants. In terms of prior criminal record, $56 \%$ of the defendants had none or only a minor record, while $14 \%$ had a prior prison record ${ }^{10}$ (B.C.S., 1970: 22-28).

The Los Angeles. Superior Court is divided into eight districts, the largest being the Central district, located in downtown Los Angeles. The Central district was the research site for this study. About $40 \%$ of the cases in the county were handled in the Central district. The Public Defender represented about $70 \%$ of the defendants in the Central district, a higher figure than for the entire county.

Within the Central district, all defendants were arraigned in the Master Calendar Department. Most defendants pleaded not guilty at this arraignment and the Presiding Judge assigned each a date and courtroom for trial. ${ }^{11}$ There were 26 trial departments. Associated with each one was a judge, 2 or 3 deputy District. Attorneys (hereafter D.A.'s), a clerk, reporter and bailiff. Also, several deputy Public Defenders (hereafter P.D.'s) usually had settings for cases in the same courtroom. Needless to say, this 
daily interaction of participants in each courtroom led to certain mutual expectations and predictions about bargaining behavior and sentencing behavior.

\section{Pre-Trial Screening of Cases}

After a defendant has been arrested on a felony charge, and police have investigated his case, the D.A.'s office decides whether or not to prosecute. The D.A. may decide to file a complaint for felony prosecution, refer the case to the City Attorney for misdemeanor prosecution, or reject the case completely. In Los Angeles, prosecutors exercise considerable discretion at this point, filing felony complaints on only about one-half of the felony arrests (Klein, 1957; (Southern California Law Review, 1969; Greenwood, et al., 1973). If a felony complaint is filed, the next screening occurs at the preliminary hearing.

At the preliminary hearing (held about two weeks later), the Municipal Court judge decides whether there is reasonable or probable cause to believe that the defendant is guilty of the offense charged. About 15-20\% of the cases are terminated prior to Superior Court prosecution. While most of these are dismissed, some may be prosecuted further-as felonies (the D:A. may refile the complaint), as misdemeanors, or as cases in juvenile court or in other jurisdictions $^{12}$ (Graham and Letwin, 1969; Greenwood, et al., 1973). The Grand Jury is used infrequently in Los Angeles; 99\% of defendants are formally charged by the filing of an information in Superior Court (B.C.S., 1970: 10).

Approximately two weeks after the preliminary hearing, the defendant appears in the Master Calendar Department of Superior Court to be arraigned and to enter his plea. As there may be a hundred defendants in this court on a given day, neither the prosecutors nor the defense attorneys, have time for much discussion or plea negotiation at this stage. About three percent of the defendants plead guilty at the arraignment (Greenwood, et al., 1973: 104). The rest plead not guilty and are assigned a date and courtroom for trial (the trial date is usually seven or eight weeks away).

Once a case is sent to its trial department, investigation and planning for final disposition may begin, as the case is now in the hands of the P.D. and D.A. who will be responsible for trying it. Prior to this point, different P.D.'s had represented the defendant at the preliminary hearing in Municipal Court and at the arraignment and plea in Superior Court. Likewise, different D.A.'s had filed the complaint and prosecuted the case at each of the subsequent proceedings. 
Upon first evaluating a case, a P.D. in trials will determine whether there are any constitutional issues of search and seizure involved; if so, he will seek a dismissal in a separate hearing, on a motion of $\$ 1538.5$ of the Penal Code to suppress evidence which may have been illegally obtained. Another pretrial motion frequently raised by defense is based upon $\S 995$ of the Penal Code, seeking to quash the information because of insufficient evidence. These pretrial hearings are fairly common, occurring in an estimated $20 \%$ of the cases. They are generally independent of any plea negotiations and are quite adversarial in nature.

In summary, by the time a case has reached its trial date, it has survived extensive prosecutorial screening, some additional screening at the preliminary hearing, and many of the evidentiary and procedural issues have been resolved.

The next section will discuss aspects of the sentencing process. Normally, discussion of sentencing is presented after a discussion of disposition, rather than before. However, the disposition process only becomes understandable when it is viewed in the context of the anticipation of punishment. It is after consideration of the sentencing possibilities that strategies of plea negotiation are developed and the decision to plead or go to trial is made.

\section{Sentencing}

All of the cases in court, by their definition as felonies, are punishable by at least one year in state prison. By California's indeterminate sentencing laws, the actual length of a prison term is determined (within a range set by law) by the Adult Authority, not by the trial judge. However, of 25,642 felony defendants convicted in 1970 , only $6 \%$ were sentenced to state prison, $70 \%$ received probation (some with jail time), $15 \%$ received county jail sentences, and $9 \%$ received other commitments such as California Youth Authority, fine, California Rehabilitation Center, or Department of Mental Hygiene (B.C.S., 1970: 5) ${ }^{.3}$

The P.D.'s know this pattern of sentencing, and they also know how different kinds of cases are likely to fit into this pattern. Two key factors in the sentencing decision are the defendant's prior record and the type of offense. Defendants without criminal records can anticipate leniency from the court. For example, almost $90 \%$ of convicted defendants in 1970 with minor or no prior records received probation or a fine, compared with about $55 \%$ of defendants with major or prior prison records. And further, only $8 \%$ of defendants with no record were sentenced to county jail or prison compared with $50 \%$ of defendants with prior prison records (B.C.S.,n.d.). 
Penalties for different offenses are prescribed by law, but actual sentencing decisions reflect, in addition, the judges' views on the severity of different crimes. Cases are perceived according to categories of "normal crime" - categories of offense types based upon knowledge of typical patterns in committing such offenses and the characteristics of the typical offender associated with that crime (Sudnow, 1965). Thus, some crimes which may be considered serious by the state legislature, are not so viewed by the court, because these offenses do not typically display dangerous or professional criminal activity - for example, bookmaking, homosexuality, marijuana, pills and other victimless crimes.

One judge explained:

Although the type of punishment legally defines a "felony," in actual fact - because "felony" carries with it other implications - an offense may be called a "felony" for reasons other than punishment. For example, bookmaking. Now, that crime used to be a city ordinance, a misdemeanor. But a police officer is only allowed to arrest on a misdemeanor charge if he witnesses the offense. But, of course, bookmaking goes on behind closed doors, so the officers weren't able to sustain their charges.

When bookmaking is made a felony, then the cops can come in and charge for an offense which they didn't witness. Bookmaking always gets a misdemeanor sentence though. Another example of this is these pill cases. They were made felonies just a few years ago. It was a clear example of the Legislature panicking. The Legislature thinks that the answer to all crime is to simply increase the punishment. Now that's absurd. Punishment is not going to solve the problem of pills. I've never seen one pill case go to the state prison. (Emphasis added)

Much of the information for the sentencing decision comes from the "probation report" which is prepared by an officer of the probation department. The report includes a summary of the defendant's record, background, and the circumstances of the offense, along with a recommendation on the advisability of probation. Most judges tend to follow these recommendations and, to the extent that they do not, it is usually the judges who are more lenient than the probation officers (often as a result of a plea bargain).

\section{Disposition Alternatives}

There are several possibilities for the final disposition of a case: (1) The defendant changes his plea from not guilty to guilty. The guilty plea may be to the offense as charged, to a lesser offense, or to one of several offenses charged against him. The plea may be entered with a tacit understanding of the likely sentence or with an informal indication by the judge as to the probable sentence. Or, the judge may formally promise to give a certain 
sentence on the condition that the probation report is favorable; in the event of an unfavorable report, the defendant is allowed to withdraw his plea. (2) The defendant has an abbreviated trial (without jury) on the basis of the transcript of the preliminary hearing and, if desired, with additional evidence and argument. This method of trial, known as "submission on the transcript," often operates as a "slow plea" of guilty and then involves the same kinds of bargains as to charge and sentence as in a guilty plea. (3) The defendant has a full court trial (without jury). (4) The defendant has a jury trial.((5) The case is dismissed after a pretrial motion on the evidence or "in the interests of justice." The frequency of these alternative dispositions is shown in Table $1 .^{14}$

TABle 1: Method of Case Disposition for All Felony Defendants, Superior Court of Los ANgeles County, 1970. (B.C.S., 1970: 12)

\begin{tabular}{rrl}
$\mathbf{N}$ & $\%$ & Disposition \\
15,013 & 47.6 & Guilty plea \\
10,205 & 32.3 & Trial by submission on \\
& & transcript \\
2,518 & 8.0 & Court trial \\
1,141 & 3.6 & Jury trial \\
2,694 & 8.5 & Dismissal \\
\hline 31,571 & 100.0 & Total
\end{tabular}

Submission on the transcript (S.O.T.) trials, while authorized for all of California, rarely occur in counties other than Los Angeles. Most S.O.T. proceedings substitute for guilty plea dispositions, often including discussion or bargaining beforehand. For example, the judge may commit himself (formally or informally) to what the likely sentence would be if the defendant is found guilty; or there may be an agreement whereby the defendant will be convicted of a lesser charge. The conviction rate for S.O.T. trials was $81.0 \%$ in comparison to a conviction rate of $69.8 \%$ for jury trials and $62.2 \%$ for court trials (B.C.S., 1970: 12). In some cases, the S.O.T. proceeding is used where the D.A. would like to dismiss the case but feels he cannot justify it to his superiors; so the case is submitted to the judge for acquittal. In other cases, S.O.T. is a semi-adversary proceeding where the defense concedes certain points in the case but wishes to contest others; thus, argument is focused only on the issues in conflict, not on the entire case. However, most S.O.T. trials are really "slow pleas" of guilty, with the advantages that the defendant reserves his right to appeal and does not have to admit guilt (which is also a selling point for the defense attorney to his client). Instead of referring to the choice between guilty plea and 
trial disposition, henceforth I shall distinguish between "trial" and "non-trial," with "trial" referring only to the full adversary proceedings of court or jury trial.

During the interval (roughly two months) between the defendant's not guilty plea in the Master Calendar Department and the date set for trial in a specific courtroom, the P.D. investigates the case and may argue a pretrial motion. If, after talking with his client, the P.D. thinks that a non-trial disposition would be appropriate, he approaches the D.A. with an offer. The attorneys usually do not discuss possibilities for final disposition until just before, or the morning of, the date set for trial, and it is customary for the defense attorney to approach the D.A. to suggest a plea bargain. The suggested bargain is generally based on a realistic estimate of "what the case is worth," as well as "what is available" according to D.A. office policies of charge reduction. Certain reductions are routinely available, but for others the D.A. must secure permission from his superiors before accepting a plea to a lesser charge.

Of all defendants convicted in 1970, 9\% were convicted of misdemeanor charges, $18 \%$ convicted of lesser felonies, and $73 \%$ convicted of felonies as charged. But while only $9 \%$ were convicted misdemeanor charges, $59 \%$ of the defendants were convicted at the misdemeanor level (B.C.S., 1970: 18). This is due to an interesting use of $\$ 17$ of the Penal Code-a section which defines the level of conviction according to the sentence imposed. That is, felonies in California are divided into "mandatory" felonies and "optional" felonies. A mandatory felony is punishable only by imprisonment in state prison (or death, in 1970), while an optional felony is punishable by prison, county jail or fine. ${ }^{15}$ (For most cases involving either type of felony, however, probation can be imposed.) By $\$ 17$ of the Penal Code, defendants who are convicted of an optional felony charge may receive a misdemeanor level of conviction if the judge imposes a misdemeanor-type sentence. The D.A.'s are reluctant to accept pleas to misdemeanor charges, preferring instead to arrange a disposition to an optional felony and to leave the decision to the judge whether to make the conviction a misdemeanor by sentence. Charge reduction is most important in cases involving mandatory felony offenses, because the court cannot give a misdemeanor sentence on a mandatory felony; a disposition to a lesser, optional felony leaves the choice open as to whether a misdemeanor or a felony sentence will be imposed.

Thus, a key question for a defense attorney seeking a non- 
trial disposition is how the judge will exercise his discretion in sentencing. P.D.'s try to have their cases "disposed of" (settled without trial) by judges whose sentencing behavior they can fairly accurately predict, or by judges who will "chamberize," that is, who will indicate to defense counsel in chambers what the likely sentence will be. If the judge to whom the case is assigned for trial does not appear favorable to his client, the P.D. (with the approval of the D.A.) can have the case transferred to a "short cause" court. There are two short cause courts among the 26 trial departments; they are designed to handle only guilty plea dispositions or S.O.T. trials which can be heard in less than one hour. Judges who are known to be lenient sentencers are generally assigned to the short cause departments, thus facilitating non-trial dispositions.

After a P.D. has arranged a plea or S.O.T. disposition, he returns to his client for the final decision on disposition. P.D.'s vary as to how strongly they will advise their clients at this point. ${ }^{16}$ Likewise, defendants differ as to their willingness to accept a bargained disposition or to insist on a trial. Some cases go to trial because of disagreement between the defendant and his attorney, not because of disagreement between the P.D. and the D.A. ${ }^{17}$

After this brief overview of the disposition process, I return to the question of how P.D.'s decide between non-trial and trial disposition as the best procedure for resolving a case. Data for the decision come from the P.D.'s investigation of the case: the defendant's version of what happened, the arrest report made by police, the transcript of the preliminary hearing, interviews with possible witnesses, examination of any physical evidence, and any other pertinent information. All of this, plus the defendant's background and prior criminal record, is evaluated in terms of the chances of acquittal and the possibilities in sentencing. This evaluation reflects a thorough knowledge of the outcomes of many other cases and a familiarity with judge and jury behavior on issues of reasonable doubt and judicial behavior on sentencing.

Two features of a case appear to be most important for the P.D.'s decision on disposition strategy: the strength of the prosecution's case and the seriousness of the case, in terms of the likely punishment on conviction. These features, in combination, yield a typology of cases which is useful for analysis of dispositions. This typology is developed below.

"Dead bang" cases are cases with very strong evidence against the defendant and with no credible or consistent explanation by the defendant for innocence. "Dead bang" is a term used by P.D.'s 
to indicate high chance of conviction; P.D.'s estimate that the majority of their cases are "dead bang" cases. "Reasonable doubt" cases, those with limited or conflicting evidence and some plausible defense, are essentially of two kinds. In one type of "reasonable doubt" case, the doubt centers on the degree of the defendant's involvement in the crime or on the gravity of the offense so that there is a chance of acquittal on the original charge, but still a high chance of conviction on a lesser criminal charge. In the other type of "reasonable doubt" case, the doubt arises from insufficient evidence either to connect the defendant with the crime or to prove that any crime has been committed; in these cases there may be a good chance of complete acquittal.

The seriousness of a case refers to the probability of a severe sentence on conviction. A "serious" case, then, is one with a high chance of a state prison sentence. Either a bad criminal record for a defendant or a severe offense (such as a mandatory felony) identifies a case as "serious." All of the criteria used in sentencing, such as the defendant's background (age, family, employment, etc.) and the circumstances of the offense are relevant to the determination of whether a case is "serious" or "light." "Light" cases are those with no real possibility of a state prison sentence, and a good chance of a sentence of probation.

The terms presented above, "dead bang" vs. "reasonable doubt" and "serious" vs. "light" cases, are described each as dichotomous categories, but clearly strength and seriousness are continuous. Some cases surely fall between the extremes. Nevertheless, these categories are often used by the P.D.'s as they talk about their cases, and they are useful for explaining the processes of case disposition. The next two sections illustrate how the categories of strength and seriousness interact to produce trial or nontrial dispositions.

\section{CASE DISPOSITION: THE "LIGHT" CASE}

\section{The "Dead Bang" Case}

Conviction is very likely in these cases, because of the strength of the prosecution's case, and since the cases are "light," there is no chance of a state prison sentence and a good chance of probation. These cases are resolved by a non-trial disposition, either a guilty plea or a trial by submission on the transcript. There is little explicit bargaining accompanying most of these dispositions because specific outcomes are fairly predictable. It is understood that the D.A. will get his conviction and the defendant will get a lenient sentence and, further, both parties know 
the sentencing practices of the judge hearing the case (and of the alternative judges in short cause) and the kinds of charge reductions and dismissals which are permitted according to D.A. office policies. Thus, most case outcomes are arrived at routinely, with minimal conflict between the P.D. and the D.A. A judge, quite involved with committees studying court processes, commented:

There is a large universe of practices which, for lack of a better word, I shall call "pre-plea discussions" regarding the outcome of a case. A subset of these practices are the actual "plea bargains." But pre-plea discussions encompass a much larger range than plea bargaining, and are actually a more appropriate way of talking about what goes on in court these days.

When asked by the author to describe some pre-plea discussions which are not actual plea bargains, the judge continued: ${ }^{18}$

\begin{abstract}
On a three count forgery case, the defense attorney asks the D.A., "Can I have one count?" The D.A. says, "Yes, which one?" The defense attorney says "Count 2." And that's it. No bargain has been made. No promise made that counts 1 and 3 will be dismissed in exchange for the plea to count 2. It's simply that everyone knows what the standard practice is. Or here's another example. The defense attorney comes into court and asks the D.A., "What does Judge Hall give on bookmaking cases?" The D.A. asks if there are any priors. The attorney says "no," and the D.A. says, "He usually gives $\$ 150$ fine on the first offense." The attorney says, "Fine. We'll enter a plea to count one." Again no promise was made by anybody. It's just that everyone knows what customarily will happen. This is what I mean by the larger arena of pre-plea discussions. (Emphasis added)
\end{abstract}

In another example, the defendant was charged with burglary. On the morning of the trial date, the P.D. and D.A. spoke briefly and agreed to transfer the case to a short cause department. Since the defendant was in custody, the P.D. wanted to waive the probation report (which would take an additional 3-4 weeks to prepare) and have the defendant sentenced immediately. The P.D. was familiar with Judge Greene's sentencing practices (the judge in short cause) and court was busy that afternoon, so the attorneys did not discuss the case in chambers before disposition. When the judge called the case, the P.D. announced that his client wished to change his plea of not guilty to guilty. Then the D.A. "took the waivers," that is, he asked the defendant a series of questions to ascertain that he understood the nature and consequences of the proceedings, that he waived his rights to jury trial, cross-examination of witnesses, and self-incrimination, and that no promises or threats had been made to induce the plea of guilty. Judge Greene then accepted the plea, making it second degree burglary, and the following occurred: 
P.D.: Your Hcnor, we request immediate sentencing and waive the probation report.

Judge: What's his record?

P.D.: He has a prior drunk and a GTA (Grand Theft Auto). Nothing serious. This is really just a shoplifting case. $\mathrm{He}$ did enter the K-Mart with the intent to steal. But really all we have here is a petty theft.

Judge: What do the people have?

D.A.: Nothing either way.

Judge: Any objections to immediate sentencing?

D.A.: No.

Judge: How long has he been in?

P.D.: 83 days.

Judge: I make this a misdemeanor by P.C. $\$ 17$ and sentence you to 90 days in County Jail, with credit for time served.

Interestingly, the P.D. refers to offenses in terms of their social reality rather than their legal definitions. That is, legally the case may be a burglary, but "really" it is just a petty theft. Likewise, Grand Theft Auto may be a serious crime according to the Penal Code, but because of the circumstances which typically surround it, everyone knows it's usually "nothing serious." The P.D.'s comments below to the author indicate some of the considerations involved in formulating a disposition:

P.D.: I could have gotten a disposition of a plea to petty theft (a straight misdemeanor). But knowing Greene, he'd make it second degree (an optional felony) with a misdemeanor sentence.

L.M.M.: But why not plead to petty theft, instead of pleading to the felony?

P.D.: Because petty theft can be counted as a prior.

L.M.M.: What do you mean?

P.D.: Petty theft with a prior petty theft or a prior felony conviction is automatically a felony. So with a plea to a felony but with a misdemeanor sentence, that makes this burglary a misdemeanor. Thus, it could not be counted as a prior for petty theft.

Now if the guy was completely clean and probably never going to get into trouble again, then I'd want him to plead to petty theft, because it looks better on his record. But this kid's in the ghetto and caught up in that and will probably get into trouble again. So it's better for him if he doesn't have a petty theft prior.

Also, you consider the prosecutor. He wants a plea to a felony because it makes their statistics look better. But I know it doesn't really make much difference. Employers or the police go by a guy's rap sheet which shows arrests. And after all, it stays as a felony arrest 
even if he would have pled to the misdemeanor. But this way, the prosecutor thinks I'm giving him a break. So maybe later he'll give me a break.

In plea discussions, P.D.'s bring out anything in the circumstances of the case or about the background of the defendant which would justify a lenient disposition. P.D.'s refer to facts which minimize the gravity of the offense ("nothing was taken" in a burglary or "no one was hurt" in a robbery), which mitigate the defendant's involvement ("the defendant was drunk at the time"), or which point to the defendant's good character ("he's enrolled full-time in school" or "he's supporting his sick mother"). When the P.D. is particularly interested in charge reduction, he also points out any contradictions or weak points in the prosecution's case.

\section{The "Reasonable Doubt" Case}

Where doubt in a case centers on the degree of the defendant's involvement in a crime (that is, where the case for the original charge is weak, but where there is strong evidence for guilt on a lesser charge), the case is usually resolved by a non-trial disposition to a lesser charge. This occurs frequently in cases which P.D.'s consider were "overfiled" initially. Most D.A.'s deny that their cases are overfiled, saying instead that they are simply filed at the highest possible level permitted by the evidence. There are certain routine charge reductions which (as in the disposition of the "dead bang" case above) generally require no negotiation to obtain. For example, a suspect arrested driving a stolen car may be charged with Grand Theft Auto and Felony Joyriding; he then usually pleads guilty to the lesser count of Felony Joyriding. Or, a defendant arrested with a large quantity of marijuana or dangerous drugs is charged with Possession for Purposes of Sale (which carries a much heavier sentence than simple Possession) and then is convicted by plea or S.O.T. trial of simple Possession.

In the following example, the defendant (who was released on bail) was charged with burglary of an automobile (an optional felony offense). The P.D. and D.A. discussed the case in the judge's chambers for disposition to a lesser charge based upon a crucial weakness in the prosecution's case:

P.D.: We'll submit it (S.O.T. trial). We'd like either an auto tampering or a petty theft (both are straight misdemeanors). He admits taking the Panasonic, but ....

Judge: (interrupting) Yeah, I've read this transcript. There's no evidence that the car was locked. (Emphasis added.) 
After the discussion in chambers, the judge resumed the bench and called the case. The P.D. announced that the case would be submitted on the transcript, "with a maximum possible conviction of auto tampering, Vehicle Code $\$ 10852$." The D.A. concurred and "took the waivers" from the defendant. In addition, the defendant stipulated that "in all probability" he would be found guilty. The case was a "straight submission" with no additional argument or testimony and the defendant was found guilty of auto tampering, a violation of Vehicle Code $\S 10852$.

For cases which are weak and present reasonable doubt that the defendant is guilty of any offense, P.D.'s seek a complete acquittal. If the weakness is apparent on the basis of the transcript of the preliminary hearing, and if the P.D. thinks that the D.A. handling the case will be receptive to the disposition, then the P.D. discusses the case with him to arrange an acquittal. If the D.A. agrees, he may talk to his superiors for permsission to dismiss the case, but usually he prefers to talk to the judge, agreeing to an S.O.T. trial for a not guilty finding. For example, one P.D. described a D.A. who was not intimidated by office pressures against dismissing cases:

In Beal's court, the D.A. was good. He'd come into chambers and tell the judge, "Lcok, I've got this case, and I think the cop is lying, so I don't want to call him as a witness." And Judge Beal would dismiss the case.

Another D.A. explained how he used the proceeding of S.O.T. for a not guilty verdict:

If you've got an exceptional case-one which is weak and there's a good chance that the defendant may be innocent - then you don't want ito take it before a jury because you never know what they'll do. And besides you don't want to try it because it's such a bad case. So you chamberize with the judge and agree to S.O.T. with a not guilty verdict. . . . For example, where there is direct evidence for the corpus of a crime but only indirect evidence to link the defendant to the crime. That is, there could be a completely innocent explanation of the defendant's connection to the scene. If it's a weak case but I'm convinced he's guilty, then I'll try it. But on a weak case where the defendant could be innocent, I don't like to trust the vagaries of a jury. (Emphasis added.)

P.D.'s do not consider the majority of D.A.'s to be as willing to agree an acquittal as the D.A. quoted above. Thus, on most weak cases with reasonable doubt on the defendant's guilt, the P.D.'s would go directly for adversary trial disposition. Since the cases discussed in this section are "light," there would be few or no sentencing risks involved by a trial disposition, as the sentence 
even after trial would probably be quite lenient. Most P.D.'s interviewed did not believe that defendants were sentenced more severely after a trial conviction than if they had.been convicted on a plea or S.O.T. disposition. This was particularly true where the defendant had a clean record and the offense was considered minor. As the defendant's record lengthened and the circumstances of the offense appeared more serious, trial might involve some sentencing risks: the defendant could be assured of leniency in a non-trial disposition, but he would have to take his chances on the probation report after conviction by trial. Nevertheless, these risks were usually not considered very great; P.D.'s were more interested in securing a complete acquittal than in securing a lenient sentence. In these cases, there was usually no discussion or bargaining with the D.A. prior to disposition, and the P.D.'s took the cases directly to court or jury trial.

\section{CASE DISPOSITION: THE "SERIOUS" CASE}

There is usually more conflict involved in the resolution of "serious" cases than of "light" cases because both D.A.'s and judges hesitate to exercise discretion in cases involving grave offenses or defendants with bad records. In resolving a "light" case, P.D.'s point out factors relating to the offense, the defendant's background, and weakness in the prosecution's case in order to arrange a non-trial disposition. But in "serious" cases, there is more likely to be negotiation and bargaining over these elements, and a non-trial disposition which is favorable to the defendant is much more difficult to obtain.

\section{The "Dead Bang" Case}

In these cases, where there is a good chance of conviction and a possibility of state prison sentence, P.D.'s bargain to secure a non-trial disposition with as lenient a sentence as possible (and, at the least, an indication of no state prison). Some "serious" cases take little bargaining, as all parties soon concede the mitigating factors involved; a plea or S.O.T. disposition is easily arranged in these as they are "not really state prison cases." In other cases, the P.D. and D.A. may negotiate for some time before agreeing on a disposition; or they may fail to agree, in which case the P.D. will take the case to adversary trial.

The following case illustrates a process of lengthy negotiations and continuances in resolving a very "serious," very 
"dead bang" case. The defendant was charged with burglary; he was in custody and had five prior burglary convictions. There was evidence that he had been drinking just before his arrest. The P.D. had continued the case once already and was having difficulty reach a plea agreement with the D.A. (The P.D. said that $90 \%$ of the time he and this D.A. agreed on "appropriate dispositions," but in this case they did not.) The P.D. described the case:

The guy was caught driiling a hole in the wall next to a safe in a store. There's no defense at all. And he's got five prior burglary convictions - and they're all good priors. I wanted to go to Greene (a judge in short cause) and plead him. Maybe we could keep him out of state prison then. In any other court it's prison for sure. The guy's just an old drunk. But Davis (the D.A.) wouldn't agree to going to Greene. And the D.A. has to consent to short cause. He figured with five priors and drilling a hole in the wall by the safe, that the guy's not just an old drunk. That he's a professional burglar. I don't think so, though.

The difference of opinion on this case centered on an evaluation of the defendant's character: that is, if he was "a professional burglar" as the D.A. claimed, then he should go to state prison; but if he was "just an old drunk" as his attorney argued, county jail would be appropriate.

Because of calendar pressures later, the D.A. did consent to transfer to short cause and there the defendant pleaded guilty. The P.D. explained that he did not talk with the judge about sentencing before his client pleaded guilty because,

We only chamberize where the D.A. and myself are in accord we've agreed on what we want and go into chambers to tell the judge. But here in this case, there was a straight conflict between the D.A. and myself. So there's no point in talking in chambers. ${ }^{19}$

The probation report came back with a generally unfavorable recommendation, as did an additional report from a 90-day diagnostic study by the Department of Corrections, but the P.D. argued strongly for lenient consideration. Finally, the judge sentenced the defendant to one year in County Jail with no credit for time served (about 9 months). The P.D. commented:

Two years County Jail is better than even six months of The Joint (state prison) - especially since prison might have kept him 5 to 10 years because of his record.

In "serious" cases where the P.D. can see no possibility of avoiding a state prison sentence, he may resolve the case without trial through some kind of bargain on the prison sentence. If the defendant is charged with several severe offenses, he 
may plead to one and thus avoid the possibility of consecutive sentences. Or, for example, if the defendant is charged with first degree robbery with an allegation of Great Bodily Injury (which carries a fifteen to life prison term), a deal might be arranged where he could plead to second degree robbery (with a prison term of one to life). However, there is conflicting opinion among P.D.'s on the value of these kinds of "bargains," since judges tend to give concurrent rather than consecutive sentences even on trial convictions of multiple charges. Besides, the Adult Authority determines the final release date for defendants in prison, and it may consider the original facts and charges in the case, not just the charges to which the defendant pleaded guilty.

Thus, for many cases where the P.D. cannot successfully bargain for a non-state prison sentence, a trial disposition is chosen. "The defendant's got nothing to lose-he'd go to The Joint anyway," one judge commented:

If the defendant did what he did and he's going to prison for it anyway - particularly if it's a heinous offense - then he's not going to get any consideration from me or the probation department. In that case, his lawyer will tell him that he can't do anything for him, so he might as well go to trial and take his chances on an acquittal. (Emphasis added.)

Typical cases which are likely to go to trial because (the judge continued) "there is no room for negotiation" included:

Armed robbery - that gets five to life. Forcible rape. First degree burglary with maybe some injuries involved. Murder cases, Some child molestation cases.

\section{The "Reasonable Doubt" Case}

In "serious" cases where there is a possibility of acquittal on the original charge (but likely conviction on a lesser charge) or a possibility of a complete acquittal, the sentencing risks involved in a trial disposition are high. Since "serious" cases usually involve mandatory felonies and/or defendants with prior felony conviction, the judge may be prevented by statute from granting a misdemeanor sentence or probation if the defendant is convicted as charged. But if he is convicted of a lesser charge, or if the D.A. offers no evidence on the "priors" (as might occur in a bargained disposition), the judge possesses the discretion to grant a more lenient sentence, and he is usually more willing to exercise this discretion for leniency. Most attorneys interviewed indicated that defendants who have been convicted at trial are not sentenced more severely than they would have 
been had they been convicted in a non-trial disposition;"1" with the qualification that, as one D.A. noted:

\begin{abstract}
What often happens, though, is that by going to trial he (the defendant) gets convicted of a lot more serious charge than if he had taken a disposition to a lesser charge. Like we told them in that . . . case this morning: robbery conviction with a finding of "armed" would mean state prison. In (non-trial) disposition, the judge is saying the defendant will get something less for pleading guilty. But if the case goes to trial, then the judge is no longer bound by any earlier conditions .... A plea bargain may involve a different charge than the charge at trial, that's why the sentences would be different. (Emphasis added.)
\end{abstract}

If a P.D. feels that a case is "overfiled," (that is, that there is a good chance of conviction on a lesser charge but that there is reasonable doubt on the original charge) he will probably use the weak points in the prosecution's case and any mitigating factors to secure a non-trial disposition to a lesser charge, with an indication or promise of a lenient sentence. For example, in a case involving armed robbery charges against two defendants (both of whom were released on their own recognizance), the D.A. and two defense attorneys (a P.D. and a court-appointed private attorney) agreed on a non-trial disposition to the lesser charge of Grand Theft Person. They then talked to the judge who promised the defendants a misdemeanor sentence, conditioned upon a favorable probation report. The D.A. described the case and explained his considerations in making the plea bargain:

The defendants had no aggravated involvement with the law previously. One of them had only a few drunk arrests and a conviction of disorderly conduct, a minor thing. The other defendant had one drunk driving, I think, and a possession of pills that had been dismissed. He had served in the armed forces and received an honorable discharge. He had been overseas and even got a medal of some sort. They are both employed.

The deal was: They had been drinking heavily and were outside a bar and stopped this guy. The victim said they pulled a gun on him and demanded his money and so forth. They took his wallet, keys, and something else - some change or a watch, I think. They were caught just a few minutes later and all the victim's belongings were in the defendants' car. But there was no gun. Now robbers don't just throw away a gun if they had one. I mean, this is something of value. And they were caught immediately after the incident, so the evidence on the presence of the gun is very weak. The victim had been drinking in that bar all day long and was quite drunk, so he's not that much help. And the defendants were drunk when they were arrested-one had a .10 and the other a .18 blood alcohol reading. A person is presumed to be drunk by law when the alcohol reading is .10 .

So this case is not like when some fellows march into a liquor 
store with a gun and hold up the store. Or a robbery of a gas station or a grocery store. I mean this is not a classic robbery. case. It's probably more of a Grand Theft Person-just the taking of money from a person. That's why a plea to Grand Theft Person is very appropriate here. We look at the background of the individuals, how much involvement they've had with the law, and the circumstances of the case. (Emphasis added.)

An armed robbery charge is a mandatory felony with punishment of five years to life in state prison and, were the armed allegation found true, the court would be restricted from granting probation; Grand Theft Person, on the other hand, is an optional felony. Thus, although the defendants' backgrounds would call for lenient sentencing, the risks of the trial were considerable. The P.D. was uncertain whether to go for a trial or not, commenting:

We were ready to try it. But it's really a "dogmeat" case. The guys were drunk. It happened outside a bar . . . . This was a damned good deal .... The risks of the trial were high.

In court, the defendants withdrew their pleas of not guilty and pleaded guilty to Grand Theft Person (which was stipulated by the D.A. to be "a lesser and necessarily included offense of robbery"). The D.A. took the waivers and, for the record, explained to the defendants that:

Representations have been made by the court to you that, by P.C. $\$ 17$, the offense will be made a misdemeanor and handled with a county level sentence. If the probation report is not favorable and the judge decides that he cannot do this, then you may withdraw your plea of guilty.

Cases with high sentencing risks and reasonable doubt on whether the defendant was involved in the crime present the most difficult decisions for P.D.'s in the choice of disposition. Frequently these cases rest on "eyewitness identification" of the defendant by the victim (which P.D.'s consider "one of the shakiest kinds of evidence, although people usually think it's one of the strongest"). Alternative dispositions on these cases are carefully considered - both the bargains possible in nontrial disposition and the chances and consequences of trial disposition. The final decision may depend upon the P.D.'s evaluation of the chances at trial, his willingness and/or ability to encourage the defendant one way or the other, and the defendant's vehemence in protesting his innocence.

In the following case, the defendant (in custody, with one prior felony conviction) was charged with two counts of first degree armed robbery and the case was resolved by jury trial. 
According to the D.A., a young couple were sitting in their car one night when two men approached, one with a gun, and ordered them to leave the car. The men drove off with the car containing the woman's purse (which, admittedly, she had forgotten when she left the car). The next morning, police found the defendant, along with several others, stripping the car. The others got away, but the defendant was caught and charged with two counts of armed robery - Count 1 was the theft of the man's car; Count 2 was the theft of the woman's purse. The defendant clearly appeared guilty of stripping a stolen car - a very different (and far lesser) offense than the robbery charges. The P.D. described the case before the trial as follows:

My guy is accused of robbery and the victims are, you know, positive that he's the guy. But I've been talking to his sister-inlaw who will testify that he was at her house the whole night that the robbery was to have occurred. And his brothers, who look just like him, will be sitting in the front row. So the jury can see them and wonder about the "positive identification."

During the trial the attorneys were still discussing alternatives for a non-trial disposition. The D.A. had indicated earlier that:

We would have taken a plea to second degree robbery with county jail time - maybe six months. Or even to Grand Theft Person .... But they didn't want to plead. Smith is a tough P.D.

And then during a recess in the trial, the D.A. and P.D. were overheard talking:

D.A.: ... Sure, we might go with Receiving Stolen Property. That's clearly there.

P.D.: What about sentencing? I'm interested in a misdemeanor sentence. Probation and County Jail suspended, maybe. And that it be made a misdemeanor by Sec. 17. . . .

D.A.: Let's talk to the judge and tell him what we're thinking. ...

In the judge's chambers, they briefly discussed sentencing and then worked out the possible lesser offenses that would be included in the instructions to the jury (and the jury trial continued). In order to give the jury ample opportunity for compromise, there were six different verdicts possible on each. count: Not Guilty, Guilty as charged of first degree robbery or Guilty of sesond degree robbery, of Grand Theft Person, of Simple Assault (a misdemeanor), or of Petty Theft (a misdemeanor). After 30 minutes of deliberations, the jury found the defendant guilly of first degree robbery as charged on Count 1, and not guilty of Count 2. 
The P.D., needless to say, was quite disappointed, and he announced that he would move for a new trial at the Probation and Sentencing hearing." ${ }^{\prime 1}$ Later that afternoon a colleague in the P.D.'s office asked him, "How'd you do on that 'dog' you took to trial?" The P.D. described the outcome of the robbery case, adding that:

That case really bothers me-knowing that we could have had a disposition (a non-trial disposition with some kind of bargain). But the guy said he was innocent and he wanted a jury trial. I could have come down harder on him though, if I thought he didn't have a case at all. (Emphasis added.)

This last remark points to the importance of a P.D.'s own evaluation of a case and his willingness to encourage his client to accept that evaluation.

\section{CONCLUSION}

The major question investigated in this study was: What determines whether a case will be settled by plea bargaining or trial? Two factors were found to be crucial for choosing the method of disposition: the strength of the prosecution's case and the seriousness of the case, in terms of the probable punishment on conviction. A typology of cases was developed to show how P.D.'s use these factors to predict case outcomes. The P.D.'s then recommend adversary trial where the risks of trial are low and the possible gains are high. This occurs principally in three situations: (1) In a "light" case with "reasonable doubt" that the defendant committed any crime. Here, the sentencing risks of trial conviction are low, and the possible gain, complete acquittal, is considerable (and is usually not obtainable through bargaining). (2) In a "serious" case where there is a good chance of conviction (either on the original charge or on a lesser charge) and where a non-state prison sentence cannot be obtained through bargaining. Here, the sentencing risks are low since the defendant goes to prison whether by trial conviction or by plea; the possible gain is acquittal which means complete avoidance of punishment. (3) In a "serious" case where there is "reasonable doubt" that the defendant was involved in the crime. Here, trial may or may not be chosen since the risks are high, but so are the possible gains.

It should be noted that most of the cases were perceived by P.D.'s to be "dead bang" or "reasonable doubt" on the original charge with probable conviction on a lesser charge. As one P.D. commented: "Most of the cases we get are pretty hopeless-really not much chance of an acquittal." Further, most of the cases were 
perceived to be "light" as seen, for example, by the fact that $70 \%$ of convicted defendants were sentenced to probation and $59 \%$ were convicted at the misdemeanor level. Thus, the "light, dead bang" cases were most frequent and the "serious, reasonable doubt" cases were least frequent.

Some additional evidence of the importance of the seriousness of a case for determining the method of disposition comes from an examination of statistical data on all case dispositions. Recall that a "serious" case is one with a high chance of a state prison sentence-i.e., a case involving a severe offense (such as a mandatory felony) or one in which the defendant has a bad criminal record. Table 2 shows the relationship between the type of disposition and the charged offense. A rank ordering of trial disposition by offense type (Table 3 ) reveals that cases involving the most severe crimes were more likely to be resolved by trial processes than were the lighter offenses. For example, while $11.6 \%$ of the total felony dispositions were resolved by adversary trial, $36.1 \%$ of the homicides, $28 \%$ of the kidnappings, and $27.1 \%$ of the forcible rapes were settled by full court or jury trial, as compared with only $8.6 \%$ of the drunk driving, $8.2 \%$ of the marijuana and dangerous drug cases, $6.2 \%$ of the forgeries and $5.0 \%$ of the bookmaking cases.

In addition, an examination of disposition method by prior record shows that $14.1 \%$ of the defendants with prison records had their cases resolved by adversary trial, while $11.8 \%$ of defendants with major records, $10.9 \%$ of defendants with minor records and $9.5 \%$ of defendants with no record had trial dispositions - again, this is in comparison to $11.6 \%$ of all dispositions which were by trial (Greenwood, et al., 1973: 42). While this data is not directly applicable to this paper (since it includes all case dispositions those of P.D.'s and private attorneys), it does tend to corroborate the pattern suggested here.

To what extent does the trial proceeding represent a failure of bargaining? To a certain extent, it does: some "serious" cases go to trial as a result of failure to reach a compromise agreement on sentencing; others go to trial after a failure of bargaining between a P.D. and his client. However, in "light" cases with a good chance of acquittal, there is usually no bargaining prior to trial because P.D.'s accurately anticipate that most D.A's will not agree to dismissal. This paper, however, suggests that the question itself may be too simply phrased. A variety of "bargains" have been identified, ranging from the implicit understanding charac- 
terizing the disposition of many "light" cases to the explicit negotiations occurring with "serious" cases. Therefore, the concept of plea "bargaining" needs to be examined more systematically in order to distinguish among the different practices accompanying non-trial dispositions.

What other factors determine the method of case disposition? Clearly lawyer/client interaction should be investigated further, since defendants sometimes choose trial disposition in spite of their attorney's view of the risks involved. Also, on occasion, caseload pressure on the D.A.'s forces them to agree to plea bargains that would not ordinarily be approved, and thus a trial disposition may be avoided. However, this factor is not predictable by P.D.'s and so cannot be a routine feature of disposition strategy. Finally, ethnographic description gives a picture of a process at a given point in time, without necessarily accounting for changes in the process over time. Factors which may change over time and affect decisions on disposition include: variation in conviction rate by juries or judges; change in judges' sentencing behavior or their willingness to commit themselves to probable sentences; organizational changes on how cases are assigned to different judges or on the ease of obtaining transfers among judges; change in D.A. policy on permissable charge reductions; and changes in criminal law or procedure (by statute or by appellate court decisions).

The trial proceeding does not resolve the conflict over what is to be done with guilty offenders. It is the question of punishment which underlies, in part, much of the dynamics of plea bargaining. It is suggested, then, that proposals for reform of trial court processes should consider more carefully the relationship between what happens in court to what happens in prisons and probation programs. 
TABLE 2: Disposition of Felony Defendants in Los Angeles Superior Court, by Offense Charged and Type of Disposition (1970). (B.C.S., n.d.)

\begin{tabular}{|c|c|c|c|c|c|c|c|c|c|}
\hline \multirow{3}{*}{$\begin{array}{l}\text { Offense22 } \\
\text { Homicide }\end{array}$} & \multirow{3}{*}{$\begin{array}{r}\begin{array}{r}\text { Total } \\
\text { Defen- } \\
\text { dants }\end{array} \\
398\end{array}$} & \multicolumn{2}{|c|}{ Jury Trial } & \multicolumn{2}{|c|}{$\begin{array}{l}\text { Court } \\
\text { Trial }\end{array}$} & \multicolumn{2}{|c|}{$\begin{array}{l}\text { Submitted on } \\
\text { the Transcript }\end{array}$} & \multirow{2}{*}{$\begin{array}{c}\text { Guiliy } \\
\text { Plea }\end{array}$} & \multirow{2}{*}{$\begin{array}{l}\text { Dis- } \\
\text { mineal }\end{array}$} \\
\hline & & Convie. & Aequilt. & Convic & Acqul & f. Convis & c. Acqult. & & \\
\hline & & 74 & 17 & 36 & 17 & 59 & 21 & 147 & 27 \\
\hline $\begin{array}{l}\text { Manslaughter, } \\
\text { Vehicular }\end{array}$ & 69 & 3 & - & 4 & 一 & 12 & 3 & 45 & 2 \\
\hline Robbery & 1875 & 136 & 55 & 154 & 71 & 411 & 59 & 881 & 108 \\
\hline Assault & 1640 & 61 & 52 & 146 & 93 & 418 & 91 & 658 & 121 \\
\hline Burglary & 4670 & 126 & 54 & 218 & 90 & 1304 & 82 & 2456 & 240 \\
\hline $\begin{array}{l}\text { Theft, } \\
\text { Except Auto }\end{array}$ & 2092 & 26 & 25 & 102 & 81 & 504 & 188 & 939 & 227 \\
\hline Theft, Auto & 1582 & 19 & 14 & 60 & 55 & 432 & 119 & 791 & 92 \\
\hline $\begin{array}{l}\text { Forgery } \\
\& \text { Checks }\end{array}$ & 2107 & 31 & 5 & 57 & 37 & 430 & 102 & 1371 & 74 \\
\hline Rape, Forcible & 391 & 21 & 15 & 34 & 36 & 71 & 19 & 160 & 35 \\
\hline $\begin{array}{l}\text { Other Sex } \\
\text { Offenses }\end{array}$ & 769 & 40 & 26 & 53 & 57 & 216 & 33 & 296 & 48 \\
\hline $\begin{array}{l}\text { Total Drug } \\
\text { Violation }\end{array}$ & 13,824 & 198 & 68 & 603 & 363 & 3913 & 987 & 6141 & 1548 \\
\hline Opiates & 1250 & 52 & 8 & 108 & 42 & 334 & 61 & 478 & 167 \\
\hline Marijuana & 5529 & 51 & 36 & 193 & 170 & 1502 & 489 & 2293 & 795 \\
\hline $\begin{array}{l}\text { Danger- } \\
\text { ous Drugs }\end{array}$ & 6851 & 92 & 24 & 297 & 148 & 2023 & 428 & 3259 & 580 \\
\hline $\begin{array}{l}\text { Other } \\
\text { Drug Violation }\end{array}$ & 194 & 3 & - & 8 & 3 & 54 & 9 & 111 & 6 \\
\hline Deadly Weapons & 19377 & 3 & 1 & 23 & 13 & 105 & 32 & 156 & 44 \\
\hline Drunk Driving & 371 & 9 & 1 & 20 & 2 & 93 & 7 & 231 & 8 \\
\hline Hit \& Run & 109 & $\mathbf{5}$ & 1 & 6 & 3 & 27 & 3 & 62 & 2 \\
\hline Escape & 146 & 一 & 一 & 2 & 2 & 18 & 4 & 118 & 2 \\
\hline Kidnapping & 189 & 24 & 4 & 16 & 9 & 37 & 7 & 79 & 13 \\
\hline Bookmaking & 701 & 3 & 1 & 17 & 14 & 166 & 69 & 374 & 57 \\
\hline Other & 261 & 17 & 6 & 12 & 9 & 51 & 12 & 108 & 46 \\
\hline Total & 31,571 & 796 & 345 & 1566 & 952 & 8267 & 1938 & 15,013 & 2694 \\
\hline
\end{tabular}


TABle 3: Rank Ordering of Trial Disposition, by Charged Offense, of Felony Defendants in Los Angeles SuPERIOR COURT (1970). (B.C.S., n.d.)

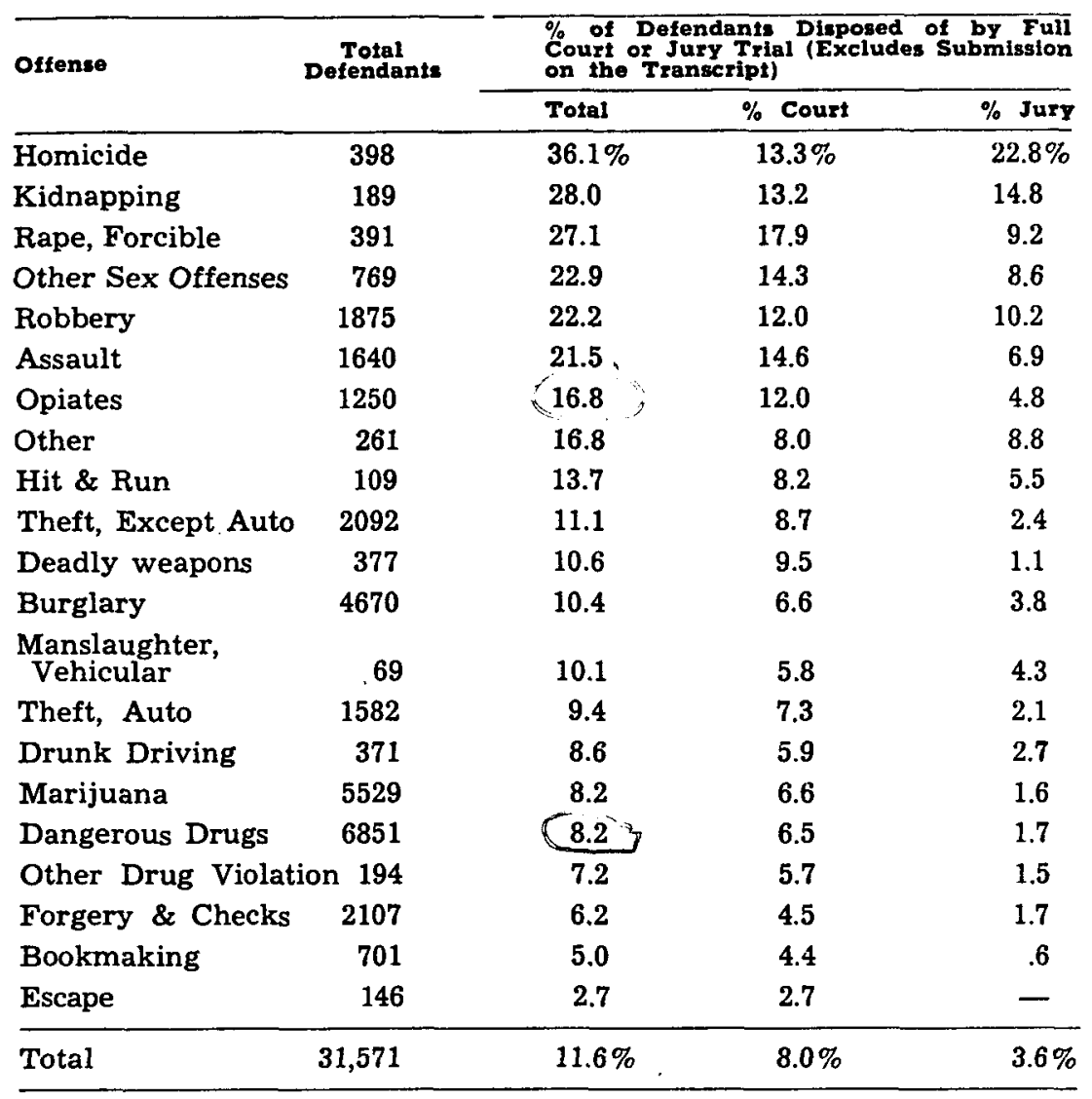

\section{NOTES}

1 For example, see Blumberg (1967), Alschuler (1968), Downie (1972), and Casper (1972). Feeley offers an interesting critique of Blumberg on this point, suggesting that "Blumberg has somewhat overstated the importance of heavy case loads" (Feeley, 1973: 418). For other anaiyses of plea bargaining, see Miller (1927), Moley (1929), Vetri (1964), Newman (1966), Skolnick (1967), and President's Commission (1967).

2 In 1927, Miller similarly noted that judicial participation in compromise settlements of criminal cases had increased with the growth of probation. He suggested: "It is hard to preserve a severe disinterestedness in the desirability of compromise when the conditions which make probation desirable appear early in the arraignment or before the case comes to trial" (Miller, 1927: 10).

3 Defendants (particularly those in custody) do however share their own knowledge and beliefs about the court and its processes. See, for example, Spradley (1970) and Casper (1972).

4 This discussion owes much to Newman (1966), McIntyre and Lippman (1970), and Levin $(1970 ; 1971)$. Levin $(1971: 207)$ first characterized the "conventional image" of criminal court processes and showed that guilty plea patterns for several urban courts "deviate quite significantly from the monolithic image in the literature."

"Feeley (1973: 417) notes that Blumberg's "Metropolitan Court" is that of New York City. For other discussions of New York's criminal court, 
see Kuh (1966-67), Alschuler (1968) and White (1971); in particular, compare Blumberg (1967) with White (1971) on the participation of New York judges in plea bargaining.

- Greenwood, et al. (1973) is the recently published report on felony prosecution in Los Angeles by the Rand Corporation. Its data provide an interesting comparison with the discussion in this paper; the report is particularly useful to compare the central district with the branch courts in Los Angeles.

7 The term "slow plea" seems to have originated in Philadelphia and Pittsburgh, although it is used in other criminal courts. A "siow plea" of guilty is a trial before a judge without a jury where "the defendant's counsel facilitates the presentation of evidence and implicitly or explicitly admits that the defendant is guilty of some offense, but does not enter a formal plea" (White, 1971: 439).

8 In all tables and references to felony dispositions, the unit of count is the individual defendant, rather than the case. A single defendant may have numerous complaints filed against him (resulting in a number of cases) but still have only one disposition. See B.C.S. (1969: 101).

${ }^{9}$ For a comparison of cases of Public Defenders and private attorneys in Los Angeles, see Smith and Wendel (1968).

10 In greater detail: $22.3 \%$ had "no known record of arrest or conviction"; $33.8 \%$ had a minor record, "which indicates a range from at least one known arrest through any number of convictions carrying sentences of less than 90 days jail or up to cne year probation"; $29.6 \%$ had a major record; "indicating any number of convictions with' sentences of at least 90 days jail or probation exceeding one year"; $14.3 \%$ had a prison record, "indicating at least one Federal cr State prison sentence." (Category descriptions are from B.C.S., 1969: 111, and figures for 1970 are from B.C.S., 1970: 22.)

11 In January, 1971, the court procedures changed so that defendants no longer came to the Master Calendar Department for arraignment and plea. Instead they were assigned directly to a trial department at the conclusion of their preliminary hearing. Most of my research was completed before that time, so I will not deal here with the effects of that organizational change.

12 Of all 9,927 felony complaints terminated in the lower courts in 1970 (for the entire county), about two-thirds were dismissed. Of the remaining third, most were reduced to misdemeanors by $\delta 17$ of the Penal Code (B.C.S., 1970: 8). For various reasons, there were very few reductions at this point in the Central district; attorneys indicated that reductions (usually from plea bargaining) were much more frequent in the branch courts. The proportion of cases terminated in the lower courts has been steadily increasing in Los Angeles, largely because of a change in $\delta 17$ of the Penal Code (in November, 1969), and then in 1971, to changes in D.A. office policy and to a California Supreme Court decision, Esteybar v. Municipal Court, 5 Cal. 3d 119 (1971).

13 These figures and those to be cited henceforth are for felony dispositions in the entire county, although descriptions given here are for the processes of the Central district only. Complete statistical data was not available for the Central district, but where it was available, it indicated that patterns in county-wide figures accurately reflected patterns in figures for the Central district.

14 The disposition patterns are fairly consistent over time, although in 1971 there was a rather sharp increase in the percentage of guilty pleas and a decline in the use of submission on the transcript (S.O.T.). Greenwood, et al. (1973:38) report that, in 1971, 55.3\% of defendants pleaded guilty and only $25.0 \%$ were tried by S.O.T. This merits further investigation.

15 Examples of mandatory felonies are homicide, kidnapping, robbery, first degree burglary, forcible rape, possession of heroin, sale of marijuana or dangerous drugs. Examples of optional felonies are assault with a deadly weapon, possession of marijuana or dangerous drugs, second degree burglary, grand theft, forgery, bookmaking.

10 Most P.D.'s, having decided that a certain non-trial disposition was better for their client than facing the risks of trial, would strongly urge the client to accept the arranged disposition. But some P.D.'s would take a great many cases to trial, explaining that they do "whatever a client wants," instead of recommending "what's best for a client." This subgroup of P.D.'s (which included 10-15\% of the attorneys in felony trials) deserves closer study because they, in effect, refuse to play the game of 
making predictions and calculating the costs and benefits of trial. Their cases are not included in the discussion which follows.

17 A complete analysis of the decision to plead should also examine the defendant's viewpoint, to determine the factors on which his decision is based. Such an analysis would consider, for example, pretrial custody status, race, age and prior record of the defendant.

${ }^{18}$ The name in this and all other quotes has been changed to preserve anonymity.

11" This is not entirely accurate. With some judges, attorneys would occasionally chamberize even when they were in conflict.

20 On the surface, the data of Greenwood, et al. (1973: 42-43) (showing that severity of sentence increases from guilty pleas and S.O.T.'s to trials) contradict this. One prcblem with their discussion is that, even controlling for charged offense and prior record (as they do), they assume that the cases settled by trial are equivalent (for sentencing purposes) to the cases settled by plea or S.O.T. This paper suggests, however, that sentencing considerations have a definite effect on the choice of disposition method.

21 After the trial, the judge indicated privately that he was disturbed that the jury had only taken 30 minutes to reach their verdict. (Note that it had taken the judge and attorneys longer than that to agree on all of the various compromise verdicts.) When asked whether the finding of first degree would mean an automatic state prison sentence for the defendant, the judge indicated that it would, as he had virtually no discretion available. Later, at the Probation and Sentence hearing, the P.D.'s motion for a new trial was denied. However, the judge then modified the verdict to find the defendant guilty of the lesser, but necessarily included, offense of Grand Theft Person. He sentenced the defendant (who was 19) to the California Youth Authority (C.Y.A.), a correctional institution for persons less than 21 years of age. Since the modified conviction was fcr an optional felony (Grand Theft Person), a commitment to C.Y.A. made the offense a misdemeanor by sentence. Hence, the final outcome of the case was better than the risks of trial conviction had indicated. However, this outcome was considered unusual. This judge was viewed by P.D.'s as being particularly fair and conscientious; most judges would not "second guess" a jury in this way.

22 Where more than one charge was filed against a defendant, "offense charged" represents the most serious one.

\section{REFERENCES}

ALSCHULER, Albert (1968) "The Prosecutor's Role in Plea Bargaining," 36 University of Chicago Law Review 50 .

BARRETT, Edward L. (1967) The Adversary Proceeding and the Judicial Process-1984. Lectures to National College of State Trial Judges.

BLUMBERG, Abraham S. (1967) Criminal Justice. Chicago: Quadrangle Books.

BUREAU OF CRIMINAL STATISTICS (B.C.S.) (1970) Felony Defendants Disposed of in California Courts: Reference 'Tables. Sacramento: State of California, Department of Justice, Division of Law Enforcement. (1969) Crime and Delinquency in California. Sacramento: State of California, Department of Justice, Division of Law Enforcement. (n.d.) Unpublished data. Sacramento: State of California, Department of Justice, Division of Law Enforcement.

BUSCH, Ted (1969) "Prosecution in Baltimore Compared to the Houston System," 5 The Prosecutor 330.

CASPER, Jonathan D. (1972) American Criminal Justice: The Defendant's Perspective. Englewcod Cliffs, New Jersey: Prentice-Hall.

DOWNIE, Leonard (1972) Justice Denied: The Case for Reform of the Courts. Baltimore: Penguin Books.

ENKER, Arnold (1967) "Perspectives on Plea Bargaining" in PRESIDENT'S COMMISSION ON LAW ENFORCEMENT AND THE ADMINSTRATION OF JUSTICE (ed.) Task Force Report: The Courts. Washington, D.C.: U.S. Government Printing Office.

FEELEY, Malcolm M. (1973) "Two Models of the Criminal Justice System: An Organizational Perspective," 7 Law \& Society Review 407.

FERTITTA, Robert (1969) "Comparative Study of Prosecutor's Offices: Baltimore and Houston," 5 The Prosecutor 48.

FRAKE, Charles O. (1969) "Notes on Queries in Ethnography," in Stephen 
A. TYLER (ed.) Cognitive Anthropology. New York: Holt, Rinehart \& Winston.

GRAHAM, Kenneth W., and Leon LETWIN (1969) A Study of the Preliminary Hearing in Los Angeles. Washington: The Institute of Criminal Law and Procedure, Georgetown University Law Center.

GREENWOOD, Peter W., Sorrel WILDHORN, Eugene C. POGGIO, Michael J. STRUMWASSER, and Peter DE LEON (1973) Prosecution of Adult Felony Defendants in Los Angeles County: A Policy Perspective. Santa Monica, Califcrnia: The Rand Corporation.

JACOB, Herbert (1965) Justice in America. Boston: Little, Brown \& Co.

KLEIN, Richard (1957) "District Attorney's Discretion Not to Prosecute," 32 Los Angeles Bar Bulletin 323.

KUH, Richard H. (1966-67) "Plea Copping," 24 Bar Bulletin of New York County Lawyer's Association 160.

LEVIN, Martin A. (1971) "Urban Politics and Judicial Behavicr," 1 The Journal of Legal Studies 193.

(1970) Urban Political Systems and Judicial Behavior: The Criminal Courts of Minneapolis and Pittsburgh. Unpublished Ph.D. Thesis, Department of Government, Harvard University.

McINTYRE, Donald M. (1968) "A Study of Judicial Dominance of the Charging Process," 59 Journal of Criminal Law, Criminology and Police Science 463.

McINTYRE, Donald M., and David ILIPPMAN (1970) "Prosecutors and Early Disposition of Felony Cases," 56 American Bar Association Journal 1154 .

MEGLIO, John J. (1969) "Comparative Study of the District Attorneys' Offices in Los Angeles and Brooklyn," 5 The Prosecutor 237.

MILESKI, Maureen (1971) "Courtroom Encounters: An Observation Study of a Lower Criminal Court," 5 Law \& Society Review 473.

MILLER, Justin (1927) "The Compromise of Criminal Cases," 1 Southern California Law Review 1.

MOLEY, Raymond (1929) Politics and Criminal Prosecution. New York: Minton, Balch and Co.

NEWMAN, Donald J. (1966) Conviction: The Determination of Guilt or Innocence Without Trial. Boston: Little, Brown \& Co.

OAKS, Dallin H. and Warren LEHMAN (1968) A Criminal Justice System and the Indigent. Chicago: University of Chicago Press.

PRESIDENT'S COMMISSION ON LAW ENFORCEMENT AND THE ADMINISTRATION OF JUSTICE (1967) Task Force Report: The Courts. Washington, D.C.: U.S. Government Printing Office.

ROSETT, Arthur (1967) "The Negotiated Guilty Plea," 374 Annals of the American Academy of Political and Social Science 70.

SKOLNICK, Jerome (1967) "Social Control in the Adversary System," 11 Journal of Conflict Resolution 51.

SMITH, Gerald W. and Max A. WENDELL (1968) "Public Defenders and Private Attorneys: A Comparison of Cases," 27 The Legal Aid Briefcase 95.

SOUTHERN CALIFORNIA LAW REVIEW [Comment] (1969) "Prosecutorial Discretion in the Initiation of Criminal Complaints," 42 Southern California Law Review 519.

SPRADLEY, James P. (1970) You Owe Yourself a Drunk. Boston: Little, Brown \& Co.

SUBIN, Harry I. (1966) Criminal Justice in a Metropolitan Court. Washington, D.C.: U.S. Department of Justice, Office of Criminal Justice.

SUDNOW, David (1965) "Normal Crimes: Sociological Features of the Penal Code in a Public Defender Office," 12 Social Problems 255.

TRAMMELL, George W. (1969) "Control of System Policy and Practice by the Office of District Attorney in Brooklyn and Los Angeles," 5 The Prosecutor 242.

U.C.L.A. LAW REVIEW INotel (1968) "Marijuana Laws: An Empirical Study of Enforcement and Administration in Los Angeles County," 15 U.C.L.A. Law Review 1499 .

VETRI, Dominick R. (1964) "Note - Guilty Plea Bargaining: Compromises by Prosecutcrs to Secure Guilty Pleas," 112 University of Pennsyivania Law Review 865.

WHITE, Welsh (1971) "A Proposal for Reform of the Plea Bargaining Process," 119 University of Pennsylvania Law Review 439. 